\title{
Intricacies in the approval of radiopharmaceuticals - regulatory perspectives and the way forward
}

\author{
Sandeep Sharma ${ }^{1}$, Sanyog Jain ${ }^{2}$, Ashish Baldi ${ }^{3}$, Rajesh K. Singh ${ }^{4}$ and \\ Rakesh Kumar Sharma ${ }^{5, *}$
}

${ }^{1}$ I. K. Gujral Punjab Technical University, Jalandhar 144 603, India

${ }^{2}$ National Institute of Pharmaceutical Education and Research, SAS Nagar 160062 , India

${ }^{3}$ Maharaja Ranjit Singh Punjab Technical University, Bathinda 151 001, India

${ }^{4}$ Shivalik College of Pharmacy, Nangal, Rupnagar 140 126, India

${ }^{5}$ Defence Food Research Laboratory, Siddartha Nagar, Mysuru 570 011, India

\begin{abstract}
Extensive research by the global scientific fraternity has led to the production of many radiopharmaceuticals of immense clinical importance. However, this increasing availability has not been matched by adequate regulatory action to back up the legal foundation for their commercial use. It is imperative for a radiopharmaceutical to have a seal of regulatory authority approval to qualify for human use. The present article highlights various regulatory requirements for approval of radiopharmaceuticals in USA, Europe, and particularly India, which does not have guidelines for their approval, and intensifies the concern for a harmonized regulatory platform of global acceptance.
\end{abstract}

Keywords: Approval, commercial use, guidelines, radiopharmaceuticals, regulatory authority.

RADIOPHARMACEUTICALS have drawn interest of the scientific community worldwide, due to their multifarious applications in diagnosis and therapy. They are unique because of the presence of two components in them pharmaceutical and radionuclide components. This distinctive nature necessitates them to cater to regulatory requirement of two regulatory bodies - pharmaceutical as well as nuclear. The former is mainly concerned with efficacy, purity, sterility, $\mathrm{pH}$, ionic strength, microbiological control, bacterial endotoxin test, particle size and number, apyrogenicity and isotonicity to ensure patient safety, while the latter is mainly concerned with radiation safety, apart from general quality parameters, not only for patients but also for workers who are continually exposed to such radioactive compounds ${ }^{1,2}$. The dual application of radiopharmaceuticals in diagnostics and therapeutics is attributed to the radionuclides contained in them which decay into more stable isotopic configurations with concomitant emission of various rays/particles. Once inside the body, radiopharmaceuticals accumulate in different

*For correspondence. (e-mail: rksharmadrl@yahoo.com) organs depending on their specific tissue distribution pattern, where they decay into different rays/particles. This emission of rays, particularly gamma rays, allows for capturing vital information of body organs by integrating it with gamma cameras. On the other hand, the emission of particles from radionuclides helps in destruction of local tumour cells, thereby exhibiting therapeutic activity. Figure 1 illustrates the various uses of radiopharmaceuticals.

Radionuclides decay by alpha, beta or positron decay, or by electron capture and isomeric transition ${ }^{3,4}$. Nuclear medicine techniques using radiopharmaceuticals make use of the radiation emitted by radioisotopes, by detecting them and then transforming them into images. Radiopharmaceuticals used for diagnosis, usually decay by gamma rays which are detected by gamma cameras. This allows for noninvasive organ imaging, while therapeutically used radiopharmaceuticals decay by emitting alpha or beta rays leading to destruction of diseased body cells. For example, in therapy, metabolic radio therapeutics are used in the treatment of late-stage cancer and thus can be substituted for chemotherapy ${ }^{5}$. Radionuclides have specific tissue distribution patterns which help in developing radiopharmaceuticals and suitably tagging them to the organ of interest where they exercise their effect leading to the destruction of localized cells followed by their normal excretion ${ }^{6}$. Figure 2 shows specific tissue distribution patterns of few important radiopharmaceuticals. Molecular imaging using radiopharmaceuticals is a promising tool in drug development research, where they find application from pre-clinical evaluation of pharmacokinetic and biodistribution to the measurement of proof of concept (POC) ${ }^{7}$. The renaissance of the applications of radiopharmaceuticals during the past few years is due to greater availability of radionuclides having appropriate nuclear decay properties, as well as the development of carrier molecules with enhanced characteristics ${ }^{8}$. Extensive research on radiopharmaceuticals has proved the application of diagnostic radiopharmaceuticals in the detection and the accurate prognosis for various critical 


\section{REVIEW ARTICLES}

diseases. Table 1 details some of the important radiopharmaceuticals currently used.

Radiopharmaceuticals also contribute significantly as a vital tool for drug development and research, where they are used to conduct various pharmacodynamics and pharmacokinetic studies. As a receptor probe they monitor pharmacodynamic activities and pharmacological profile of a drug, while direct labelling of the active principle allows for pharmacokinetic studies. Drug discovery and development is a lengthy and expensive task having the primary objective to hit the market passing through an intricate pathway of various drug approvals. However, for radiopharmaceuticals the process of drug approval is more complex as they are used for both diagnosis and therapy for which different approval requirements exist ${ }^{9}$.

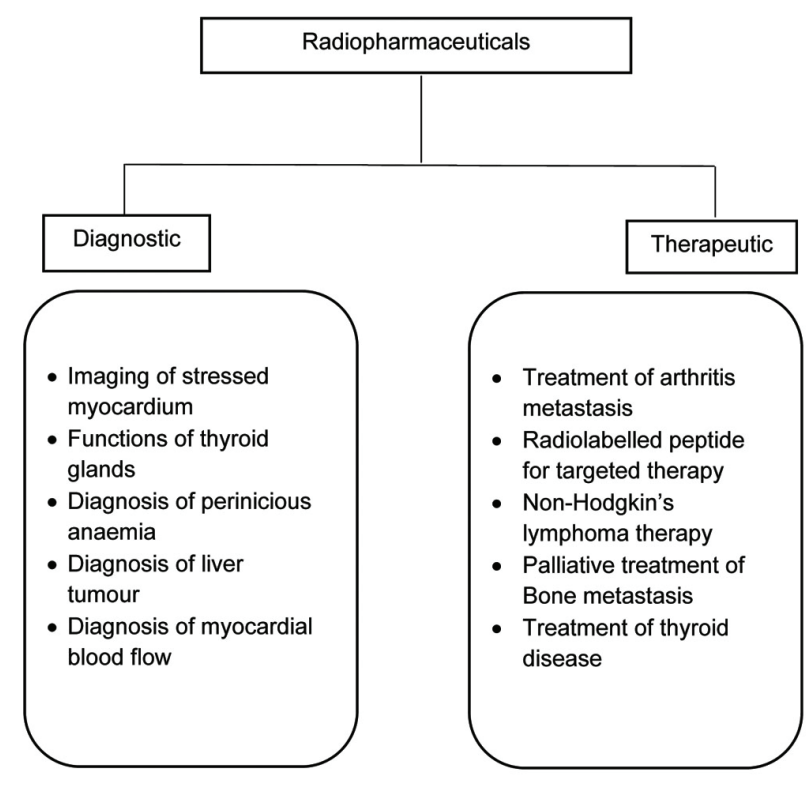

Figure 1. Various applications of radiopharmaceuticals.

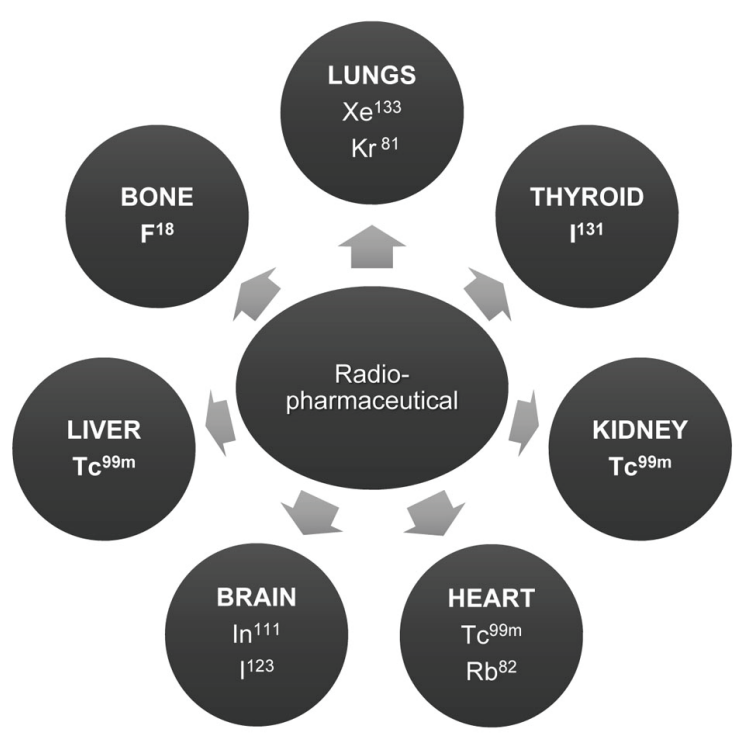

Figure 2. Radiopharmaceuticals and their tissue distribution pattern.
A therapeutic drug is estimated to cost around US\$ 850 million with an average time of almost 13 years to develop, while for diagnostic agent it is US\$ 100-200 million spanning $8-10$ years ${ }^{10-13}$. An investment of such a profound nature necessitates a smooth and quick approval process for radiopharmaceuticals so that they can be clinically used in minimal amount of time from the point of their inception. However, clinical use of any drug, including radiopharmaceuticals, is permissible only if it has been approved by the National Regulatory Authority of that particular country.

\section{Radiopharmaceuticals - a special class of pharmaceuticals}

Radiopharmaceuticals are formulations comprising of radioisotope-stickered molecules or individual radioisotopes. The presence of radionuclide-emitting radiations lends them a special case and they cannot be manufactured, handled, transported or disposed in a manner similar to regular pharmaceuticals ${ }^{14}$. One of the major concerns is the short half-life of radionuclides which imposes their release for patient use even before all the quality control tests are completed ${ }^{15}$. Some positron emission tomography (PET) drugs having short half-life involve complex manufacturing which can alter the quality of radiopharmaceuticals. Moreover, the dosage of radiations taken in by the handling staff due to continuous exposure as well as to the patient who receives this treatment, makes it pertinent to employ strict safety measures and dose optimization, since a small change in dose can produce fatal results. The issue of transporting radiopharmaceuticals from the site of manufacture to the patient also needs attention as threat to the environment and public from their spillage during transport cannot be overruled. This calls for a separate regulatory framework for them.

\section{Approval process for radiopharmaceuticals}

\section{$U S A$}

Radiopharmaceuticals are regulated in USA by the Food and Drug Administration (FDA) with the help of its different centres like Centre for Drug Evaluation and Research (CDER), which is a part of the US Department of Health and Human services. The initial days of radiopharmaceuticals were dynamic due to a relatively small cadre of practitioners with required expertise, and unclear and conflicting regulatory authorities and requirements. Also, the United States Pharmacopoia (USP) was actively working to support the development of public standards for this new class of products. The efforts finally gave results with the arrival of sodium iodide I-131 solution as the first monograph for a radiopharmaceutical in the 
REVIEW ARTICLES

Table 1. List of some of the most commonly used radiopharmaceuticals

\begin{tabular}{|c|c|c|c|c|}
\hline Radiopharmaceuticals & Composition & Type & Storage & Uses \\
\hline $\begin{array}{l}\text { Fluorodeoxyglucose } \\
\qquad\left({ }^{18} \mathrm{~F}\right) \text { injection }\end{array}$ & $\begin{array}{l}\text { Sterile solution containing } 2-\left[\mathrm{F}^{18}\right] \\
\text { fluoro-2-deoxy-D-glucopyranose- } \\
{\left[\mathrm{F}^{18}\right] \text { fluoro-2-deoxy-D-glucose; }} \\
\text { may also contain sodium chloride } \\
\text { and buffer salt }\end{array}$ & Diagnostic & $\begin{array}{l}\text { Store in sterile and } \\
\text { endotoxin-free } \\
\text { containers as single } \\
\text { dose or multiple doses } \\
\text { with proper shielding }\end{array}$ & $\begin{array}{l}\text { Detection of Paget's } \\
\text { syndrome, } \\
\text { osteomyelitis, } \\
\text { epiphyses, Hodgkin's } \\
\text { and non-Hodgkin } \\
\text { lymphoma }\end{array}$ \\
\hline $\begin{array}{l}\text { Gallium }\left({ }^{68} \mathrm{Ga}\right) \\
\text { chloride solution for } \\
\text { radiolabelling }\end{array}$ & $\begin{array}{l}\text { Clear colourless solution containing } \\
\text { gallium-68 as gallium chloride in } \\
\text { dilute hydrochloric acid }\end{array}$ & Diagnostic & $\begin{array}{l}\text { Store at temperature not } \\
\text { exceeding } 25^{\circ} \mathrm{C}\end{array}$ & $\begin{array}{l}\text { Imaging myocardial and } \\
\text { pulmonary perfusion }\end{array}$ \\
\hline $\begin{array}{l}\text { Gallium }\left({ }^{67} \mathrm{Ga}\right) \text { citrate } \\
\text { injection }\end{array}$ & $\begin{array}{l}\text { Clear, colourless sterile solution } \\
\text { containing not less than } 90 \% \text { and not } \\
\text { more than } 110 \% \text { of stated content of } \\
\text { gallium- } 67 \text { at reference date and } \\
\text { time }\end{array}$ & Diagnostic & Store at $2-8^{\circ} \mathrm{C}$ & $\begin{array}{l}\text { Detection of Hodgkin's } \\
\text { disease, lymphoma and } \\
\text { bronchogenic } \\
\text { carcinoma }\end{array}$ \\
\hline $\begin{array}{l}\text { Meta-iodobenzyl }\left({ }^{131} \mathrm{I}\right) \\
\text { guanidine injection for } \\
\text { diagnostic use }\end{array}$ & $\begin{array}{l}\text { Sterile apyrogenic solution of } \\
1-\left(3-\left[{ }^{131} \mathrm{I}\right] \text { iodobenzyl) guanidine or }\right. \\
\text { its salts }\end{array}$ & Diagnostic & $\begin{array}{l}\text { Store frozen at } \leq 0^{\circ} \mathrm{C} \\
\text { with proper shielding }\end{array}$ & $\begin{array}{l}\text { For imaging } \\
\text { pheochromo-cytoma } \\
\text { and neuroblastoma }\end{array}$ \\
\hline $\begin{array}{l}\text { Meta-iodobenzyl } \\
\text { guanidine injection for } \\
\text { therapeutic use } \\
\text { (iodine-131) }\end{array}$ & $\begin{array}{l}\text { Sterile solution containing not less } \\
\text { than } 90 \% \text { and not more than } 110 \% \\
\text { of stated Iodine-131 at reference } \\
\text { date and time }\end{array}$ & Therapeutic & $\begin{array}{l}\text { Store frozen at } \leq 0^{\circ} \mathrm{C} \\
\text { with proper shielding }\end{array}$ & $\begin{array}{l}\text { Used to treat tumours } \\
\text { of the adrenal or } \\
\text { thyroid glands }\end{array}$ \\
\hline $\begin{array}{l}\text { Samarium }\left({ }^{153} \mathrm{Sm}\right) \\
\text { ethylene diamine } \\
\text { tetramethylene } \\
\text { phosphonate (EDTMP) } \\
\text { injection }\end{array}$ & $\begin{array}{l}\text { Sterile, transparent solution containing } \\
\text { not less than } 90 \% \text { and not more than } \\
110 \% \text { of }{ }^{153} \mathrm{Sm} \text { radioactivity at the } \\
\text { time and date stated }\end{array}$ & Therapeutic & $\begin{array}{l}\text { Store at } 2-8^{\circ} \mathrm{C} \text { with } \\
\text { adequate shielding }\end{array}$ & $\begin{array}{l}\text { For treatment of intense } \\
\text { pain in advanced stage } \\
\text { due to metastatized } \\
\text { form of lungs, prostate } \\
\text { and breast cancer }\end{array}$ \\
\hline $\begin{array}{l}\text { Samarium phosphate } \\
\left({ }^{32} \mathrm{P}\right) \text { colloid injection }\end{array}$ & $\begin{array}{l}\text { White, colloidal, sterile solution of } \\
\text { samarium phosphate }\left({ }^{32} \mathrm{P}\right) \text { injection } \\
\text { in isotonic solution prepared by } \\
\text { reacting carrier } \mathrm{SmCl}_{3} \text { with phos- } \\
\text { phoric acid doped with }\left[{ }^{32} \mathrm{P}\right]-\mathrm{H}_{3} \mathrm{PO}_{4} \text {, } \\
\text { followed by the addition of gelatin } \\
\text { to form a true colloidal dispersion }\end{array}$ & Therapeutic & $\begin{array}{l}\text { Store in a single or } \\
\text { multiple-dose } \\
\text { containers at } 2-8^{\circ} \mathrm{C} \\
\text { with adequate } \\
\text { shielding }\end{array}$ & $\begin{array}{l}\text { Used for bone pain } \\
\text { palliation in skeletal } \\
\text { metastases }\end{array}$ \\
\hline $\begin{array}{l}\text { Sodium fluoride }\left({ }^{18} \mathrm{~F}\right) \\
\text { injection }\end{array}$ & $\begin{array}{l}\text { Sterile, colourless solution containing } \\
\text { not less than } 90 \% \text { and not more than } \\
110 \% \text { of flourine- } 18 \text { at reference } \\
\text { date and time }\end{array}$ & Diagnostic & $\begin{array}{l}\text { Store in sterile } \\
\text { containers as single } \\
\text { dose or multiple doses } \\
\text { with proper shielding }\end{array}$ & $\begin{array}{l}\text { Bone imaging agent to } \\
\text { define areas of altered } \\
\text { osteogenic activity }\end{array}$ \\
\hline $\begin{array}{l}\text { Sodium iodide }\left({ }^{131} \mathrm{I}\right) \\
\text { diagnostic capsules }\end{array}$ & $\begin{array}{l}\text { Contains iodine-131 in the form of } \\
\text { sodium iodide on a solid support } \\
\text { prepared using not more than } \\
150 \mu \text { l of sodium iodide }\left({ }^{131} \mathrm{I}\right) \\
\text { solution per capsule }\end{array}$ & Diagnostic & $\begin{array}{l}\text { Store in a cool and dark } \\
\text { palce with proper } \\
\text { shielding }\end{array}$ & $\begin{array}{l}\text { Diagnosis of thyroid } \\
\text { function and thyroid } \\
\text { malignancies }\end{array}$ \\
\hline $\begin{array}{l}\text { Sodium iodide }\left({ }^{131} \mathrm{I}\right) \\
\text { solution }\end{array}$ & $\begin{array}{l}\text { It is a clear colourless solution of } \\
{\left[{ }^{131} \mathrm{I}\right] \text { sodium iodide in dilute sodium }} \\
\text { thiosulphate solution }\end{array}$ & $\begin{array}{c}\text { Therapeutic and } \\
\text { diagnostic }\end{array}$ & $\begin{array}{l}\text { Store at room } \\
\text { temperature with } \\
\text { adequate shielding }\end{array}$ & $\begin{array}{l}\text { Treating hyperthyroidism, } \\
\text { and for detection and } \\
\text { ablation of residual } \\
\text { functioning thyroid } \\
\text { tissue in differentiated } \\
\text { thyroid carcinoma }\end{array}$ \\
\hline $\begin{array}{l}\text { Sodium iodide }\left({ }^{131} \mathrm{I}\right) \\
\text { capsules for therapeutic } \\
\text { use }\end{array}$ & $\begin{array}{l}\text { It is available as opaque, white gelatin } \\
\text { capsules and prepared by absorbing } \\
\text { a solution of carrier-free }\left[{ }^{131} \mathrm{I}\right] \\
\text { sodium iodide into an inert filler. } \\
\text { Iodine-131 utilized in the } \\
\text { preparation of the capsules contains } \\
\text { not less than } 99 \% \text { iodine- } 131 \text { at the } \\
\text { time of calibration }\end{array}$ & Therapeutic & $\begin{array}{l}\text { Store in a cool and dark } \\
\text { palace with proper } \\
\text { shielding }\end{array}$ & $\begin{array}{l}\text { Treating hyper-functional } \\
\text { nodular goiter, } \\
\text { Graves-Basedow } \\
\text { disease and other } \\
\text { differentiated thyroid } \\
\text { tumours }\end{array}$ \\
\hline $\begin{array}{l}\text { Sodium phosphate } \\
\left({ }^{32} \mathrm{P}\right) \text { injection }\end{array}$ & $\begin{array}{l}\text { Clear, colourless solution of disodium } \\
\text { and monosodium }{ }^{32} \mathrm{P} \\
\text { orthophosphates made isotonic by } \\
\text { sodium chloride }\end{array}$ & Therapeutic & $\begin{array}{l}\text { Store at room } \\
\text { temperature not } \\
\text { exceeding } 30^{\circ} \mathrm{C}\end{array}$ & $\begin{array}{l}\text { Diagnosis of in the treat- } \\
\text { ment of polycythaemia } \\
\text { vera, myelocytic and } \\
\text { lymphocytic leukaemia } \\
\text { and for pain in bone } \\
\text { metastasis }\end{array}$ \\
\hline
\end{tabular}


REVIEW ARTICLES

Table 1. (Contd)

\begin{tabular}{|c|c|c|c|c|}
\hline Radiopharmaceuticals & Composition & Type & Storage & Uses \\
\hline $\begin{array}{l}\text { Strontium }\left({ }^{89} \mathrm{Sr}\right) \text { chloride } \\
\text { injection }\end{array}$ & $\begin{array}{l}\text { Clear, colourless sterile solution of } \\
\text { strontium- } 89 \text { as strontium dichloride } \\
\text { and containing not less than } 90 \% \\
\text { and not more than } 110 \% \text { of stron- } \\
\text { tium- } 89 \text { at reference date and time }\end{array}$ & Therapeutic & Store at $2-8^{\circ} \mathrm{C}$ & $\begin{array}{l}\text { Used as a paliative } \\
\text { therapeutic option to } \\
\text { help relieve pain in } \\
\text { bone metastases }\end{array}$ \\
\hline $\begin{array}{c}\text { Technetium }\left({ }^{99 \mathrm{~m}} \mathrm{Tc}\right) \\
\text { DMSA injection }\end{array}$ & $\begin{array}{l}\text { Sterile solution containing not less } \\
\text { than } 90 \% \text { and not more than } 110 \% \\
\text { of stated Technetium- } 99 \mathrm{~m} \\
\text { radioactivity at reference date }\end{array}$ & Diagnostic & $\begin{array}{l}\text { Store at room } \\
\text { temperature with } \\
\text { adequate shielding }\end{array}$ & $\begin{array}{l}\text { Diagnosing lung cancer } \\
\text { and imaging renal } \\
\text { parenchymal disorders }\end{array}$ \\
\hline $\begin{array}{l}\text { Technetium }\left({ }^{99 \mathrm{~m}} \mathrm{Tc}\right) \\
\text { macrosalb injection }\end{array}$ & $\begin{array}{l}\text { White, sterile suspension of human } \\
\text { albumin in the form irregular and } \\
\text { insoluble aggregates obtained by } \\
\text { denaturing human albumin in } \\
\text { aqueous solution and labelled with } \\
\text { Technetium-99m }\end{array}$ & Diagnostic & $\begin{array}{l}\text { Store at } 2-8^{\circ} \mathrm{C} \text { with } \\
\text { adequate shielding }\end{array}$ & $\begin{array}{l}\text { Used for pulmonary } \\
\text { perfusion scintigraphy } \\
\text { as well as radionuclide } \\
\text { venography }\end{array}$ \\
\hline $\begin{array}{l}\text { Technetium }\left({ }^{99 \mathrm{~m}} \mathrm{Tc}\right) \\
\text { mebrofenin injection }\end{array}$ & $\begin{array}{l}\text { Clear, colourless solution consisting of } \\
\text { diisopropyl-iminodiacetic acid } \\
\text { (DISIDA) attached to a technetium- } \\
\text { 99m ion }\end{array}$ & Diagnostic & $\begin{array}{l}\text { Store in single- or } \\
\text { multiple-dose } \\
\text { containers at } 2-8^{\circ} \mathrm{C}\end{array}$ & $\begin{array}{l}\text { Detection of cystic duct } \\
\text { obstruction associated } \\
\text { with acute cholecystitis } \\
\text { and to detect bile leaks }\end{array}$ \\
\hline $\begin{array}{l}\text { Technetium }\left({ }^{99 \mathrm{~m}} \mathrm{Tc}\right) \\
\text { medronate complex } \\
\text { injection }\end{array}$ & $\begin{array}{l}\text { It is also called technetium }\left({ }^{99 \mathrm{~m}} \mathrm{Tc}\right) \\
\text { MDP complex injection and is a } \\
\text { sterile solution containing not less } \\
\text { than } 90 \% \text { and not more than } 110 \% \\
\text { of technetium- } 99 \mathrm{~m} \text { radioactivity at } \\
\text { reference date }\end{array}$ & Diagnostic & $\begin{array}{l}\text { Store at room } \\
\text { temperature with } \\
\text { adequate shielding }\end{array}$ & $\begin{array}{l}\text { Used as bone imaging } \\
\text { agent to delineate areas } \\
\text { of altered osteogenesis }\end{array}$ \\
\hline $\begin{array}{l}\text { Technetium }\left({ }^{99 \mathrm{~m}} \mathrm{Tc}\right) \mathrm{MIBI} \\
\text { injection }\end{array}$ & $\begin{array}{l}\text { Clear or slightly yellow solution con- } \\
\text { taining not less than } 90 \% \text { and not } \\
\text { more than } 110 \% \text { of stated } \\
\text { technitium- } 99 \mathrm{~m} \text { radioactivity, of } \\
\text { which not less than } 90 \% \text { is present } \\
\text { as }{ }^{99 \mathrm{~m}} \mathrm{Tc}-\mathrm{MIBI}\end{array}$ & Diagnostic & $\begin{array}{l}\text { Store at room } \\
\text { temperature with } \\
\text { adequate shielding }\end{array}$ & $\begin{array}{l}\text { Used for myocardium } \\
\text { imaging and perfusion }\end{array}$ \\
\hline $\begin{array}{l}\text { Thallous }\left({ }^{201} \mathrm{Tl}\right) \text { chloride } \\
\text { injection }\end{array}$ & $\begin{array}{l}\text { Sterile, clear, colourless and aqueous } \\
\text { solution of thallium-201 as } \\
\text { thallous chloride }\end{array}$ & Diagnostic & $\begin{array}{l}\text { Store in single- or } \\
\text { multiple-dose } \\
\text { container at } 2-8^{\circ} \mathrm{C}\end{array}$ & $\begin{array}{l}\text { Used for myocardial } \\
\text { and parathyroid } \\
\text { scintigraphy }\end{array}$ \\
\hline Urea $\left({ }^{14} \mathrm{C}\right)$ capsules & $\begin{array}{l}\text { It consists of }{ }^{14} \mathrm{CH}_{4} \mathrm{~N}_{2} \mathrm{O} \text { having a } \\
\text { portion of molecules labelled with } \\
{ }^{14} \mathrm{C} \text { to provide not more than } 37 \mathrm{KBq} \\
\text { of radioactivity per capsule }\end{array}$ & Diagnostic & $\begin{array}{l}\text { Store in airtight } \\
\text { containers with silica } \\
\text { gel bag at } \\
5-30^{\circ} \mathrm{C}\end{array}$ & $\begin{array}{l}\text { Used in the diagnosis of } \\
\text { Helicobacter pylori } \\
\text { infection }\end{array}$ \\
\hline
\end{tabular}

15th edition of the USP. It consisted of some important precedents like permission for distribution of product before completion of the test for sterility. The 16th revision of the USP had six additional monographs for radioactive drugs. The 1980s saw FDA beginning to explore the possibility of regulating PET drugs as new drugs requiring FDA approval ${ }^{16}$. Finally the enactment of FDA Modernization Act (FDAMA) on 21 November 1997 became an important milestone in the history of regulations for radiopharmaceuticals in USA. FDAMA's mission was to achieve advanced technological progress to address the needs of the 21 st century and directed that PET radiopharmaceuticals should be considered adulterated if not prepared according to USP standards. This also helped FDA to establish its approval procedures and current good manufacturing practice (CGMP) requirements ${ }^{17}$. The FDAMA of 1997 was further amended in 2007 as Food and Drug Administration Amendments Act 2007 (ref. 18).
Section 121 of FDAMA was an important part leading to reforms in regulation for radiopharmaceuticals in the US. Section 121(c)(1)(A) of this Act directed FDA to establish suitable approval and review procedures, including the New Drug Application (NDA) and Abbreviated New Drug Application (ANDA) for radiopharmaceuticals ${ }^{19}$. Also, around the same time, regulations concerning manufacture of PET drugs entitled 'PET Drugs - current good manufacturing practice' were announced. The main aim of this regulation was to help PET drug manufacturers understand the expectations of FDA concerning manufacture of such drugs and the suitable procedure and cautions to be followed ${ }^{20}$. It also stipulated 24-month time for manufacturers and compounders of PET drugs to get approval of clinical use of already available PET drugs. However, it was soon recognized that the manufacturers of PET drugs were unacquainted with the drug approval and review process. FDA responded to this by releasing another guidance document in August 2011 entitled 'PET 


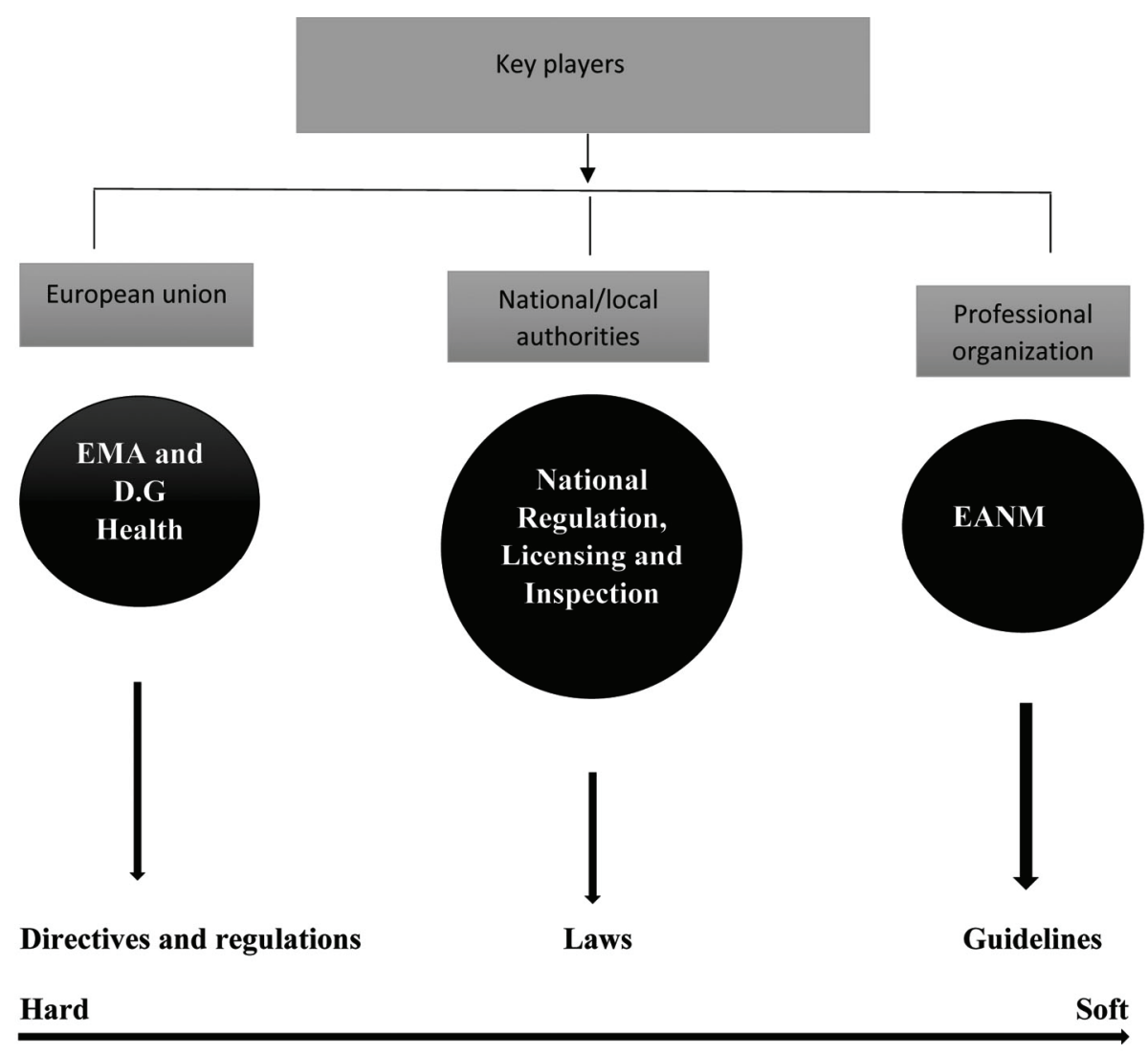

Level of legislation

Figure 3. Key operating players for drug legislation in Europe.

drug applications - content and format for NDAs and ANDAs'. This was aimed to support and provide adequate information for applicants willing to submit ANDAs and NDAs for the most frequently used PET drugs, viz. ${ }^{18} \mathrm{~F}$-sodium fluoride, ${ }^{13} \mathrm{~N}$-ammonia and ${ }^{18} \mathrm{~F}$ FDG for human use $^{21}$. Today, even the research-based radiopharmaceuticals to be used for human studies like ${ }^{18} \mathrm{~F}$-fluorothymidine, ${ }^{18} \mathrm{~F}$-fluoromisonidazole, ${ }^{18} \mathrm{~F}$-fluorodopa and ${ }^{11} \mathrm{C}$-methionine are mandated to go for either investigational new drug (IND) application or radioactive drug research committee approval ${ }^{22}$.

PET drugs can be used for both investigational as well as clinical purposes. Presently they can be used clinically in US if they have an approved NDA or ANDA regulatory status. Therefore, all the research and efforts culminate at NDA or ANDA approval. Unapproved PET drugs can be used clinically only under expanded access IND route $^{23}$. There are two different ways of submitting an NDA or ANDA - electronic or paper format. Electronic submission using common technical document (CTD) is the preferred form which helps prevent oversight or missing of any critical information. It consists of five components, modules 1-5 (refs 24, 25). Sometimes NDA or ANDA may not be possible for clinical use of radiopharmaceuticals in case of some rare diseases or for a radio- pharmaceutical with short half-life. FDA has addressed these concerns and another guideline was released which dealt with IND application of unapproved PET drugs and various expended access requirements for their clinical use ${ }^{26}$.

\section{Europe}

EudraLex, a collection of rules and regulations governing medicinal products, provides legal framework for established use of medicinal compounds in the European Union (EU). Regulatory set-up in the EU is related with legislation and harmonization amongst its members and consists of regulations or directives as a set of legal instruments. The European Commission (EC) issues various communications and guidelines to simplify the legal understanding of the concerned legislation. Several types of legislative instruments help in establishing various laws and policies in the EU. These instruments may be either binding or non-binding ${ }^{27,28}$. Regulations, directives, decisions and European Pharmacopoeia include the set of legally binding instruments, while non-binding instruments consist of various guidelines, position papers and concept papers, recommendations and opinions, 


\section{REVIEW ARTICLES}

notices, communications, etc. Figure 3 gives a better understanding of various legal instruments in Europe and their level of legislation. The EU has European Medicines Agency (EMA) which is a decentralized agency and caters to scientific evaluation, supervision and safety monitoring of medicines throughout the EU. In collaboration with its scientific advisory committees, the EMA adopts various opinions which are then ratified into legally binding decisions by EC.

Radiopharmaceuticals were exempted from various pharmaceutical legislations for a reasonably long period in Europe and kept with other exclusive products, including vaccines, blood-derived products and allergens. Focus was on radiation protection and pharmacopoeial monograph compliance to satisfy the quality parameter ${ }^{29}$. In a move towards harmonization, Directive 65/65/EEC of 1965 came into force which stipulated the need of marketing authorization for the first time in order to place any medicinal product in the EU market ${ }^{30}$. Furthermore, the council Directive 89/343/EEC of 1989 extended the scope of Directive $65 / 65 /$ EEC to radiopharmaceuticals, which completely changed their existing landscape. It called for immediate approval of well-established radiopharmaceuticals which were already in the market for many years. Also it laid down 'additional provisions for radiopharmaceuticals', as it was envisioned that the provisions, administrative actions and legal settings applicable to proprietary medicines were inadequate for radiopharmaceuticals. With time, another Directive 2001/ 83/EC came into force which contained the definition of radiopharmaceuticals, kits, precursors and generators. It also contained various articles, most important of which were articles 6 and 7, stating the need of marketing authorization (MA) for industrially manufactured radiopharmaceuticals (RP) and their exemptions in certain cases for extemporaneously preparations respectively ${ }^{31}$.

Any medicinal product, including radiopharmaceuticals, may be placed in the EU market only when a marketing authorization or approval has been issued to it. In Europe approval in one member state can be obtained by national authorization, while approval in several or all member states can be obtained by mutual recognition procedure (MRP), centralized procedure (CP) or decentralized procedure (DP) $)^{32,33}$. Thus there are several options for seeking approval to market a drug in Europe. Figure 4 highlights the procedural set-up for approval of radiopharmaceutical in Europe and the various application procedures that need to be followed.

Approval in one member state can be done by National Authorization Procedure. Such an application is restricted to only those products which are not to be authorized in more than one EU member state or for products in the initial phase of Mutual Recognition Procedure ${ }^{34}$. Medicinal products that have well proven use in accordance with Article 10(a) of Directive 2001/83/EC, as amended, are also good candidates for National Authorization Pro- cedure. Mutual Recognition Procedure consists of approval in one member state to be recognized by other member states in which the reference member state (RMS) already has marketing authorization. The concerned member states (CMS) are asked to recognize authorization approved by $\mathrm{RMS}^{35}$. The decentralized procedure is used for products that have no marketing authorization in any of the EU member states. In this type of application procedure, the applicant requests for simultaneous authorization in more than one EU member state. The procedure consists of filing the Common Request Form (CRF) by the applicant and requesting one of the member states to act as RMS, while listing the other as $\mathrm{CMS}^{36,37}$. Centralized procedure is used for certain special types of products as defined in Annexure to Regulation (EC) No. 726/2004. It consists of single application to place the medicinal product valid throughout the EU. All the validation and scientific evaluation of applications are done by the EMA and final authorization is granted by the EC following consultation with $\mathrm{CMS}^{38}$. For radiopharmaceuticals, the regulatory environment in the EU is complex and complicated. Majority of the radiopharmaceuticals are authorized in the EU under national marketing authorization - purely national MAs, while a small number is nationally authorized through MRP/DCP. Still a very small number is authorized through $\mathrm{CP}$. The EU has specific guidelines for marketing authorization for radiopharmaceuticals ${ }^{39}$.

\section{India}

The premier agency governing radiopharmaceuticals and their regulations in India is the Atomic Energy Regulatory Board (AERB) under the Department of Atomic Energy (DAE), Government of India (GoI). It is the regulatory and safety monitoring authority for radiopharmaceuticals in the country. AERB derives its regulatory functions

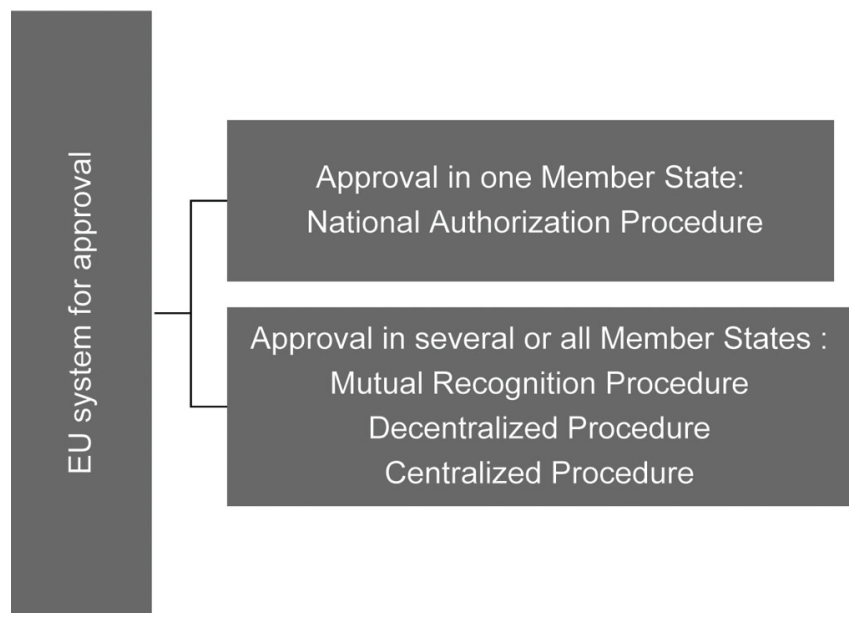

Figure 4. Procedural set-up for approval of radiopharmaceuticals in Europe. 
from various rules and notifications propagated under the Atomic Energy Act, 1962 and the Environment (Protection) Act, 1986. It is involved in site inspection and licensing of all the radiation facilities in India, and for authorization/approval of use of radiopharmaceuticals. AERB has framed specific mandatory requirements in the form of codes and guides for setting up nuclear medicine facilities. It covers the entire range of operations commencing from approval of the site, laboratory design, setting up of a facility and ultimately to its decommissioning. The various codes also specify requirements of qualified personnel and their responsibilities ${ }^{40}$. AERB considers radiopharmaceuticals as unsealed sources of radioactivity and licenses nuclear medicine centers after ensuring that they employ qualified nuclear medicine physicians and nuclear medicine technologists, who are licensed to manufacture and handle radioactivity/ radiopharmaceuticals. Figure 5 illustrates the regulatory set-up for radiopharmaceuticals in India. More recently, AERB has initiated a web based application called eLORA (e-licensing of radiation applications) for facilitating automation in the regulatory process for various radiation facilities in India, wherein all the products are listed in its portal. However, AERB does not have guidelines for 'approval' of radiopharmaceuticals for human/patient use.

The Board of Radiation and Isotopic Studies (BRIT) is an independent unit of the Department of Atomic Energy (DAE), GoI, which caters to the requirements of products and services based on radiation and isotopes in India. In conjunction with Radiopharmaceuticals Division of the
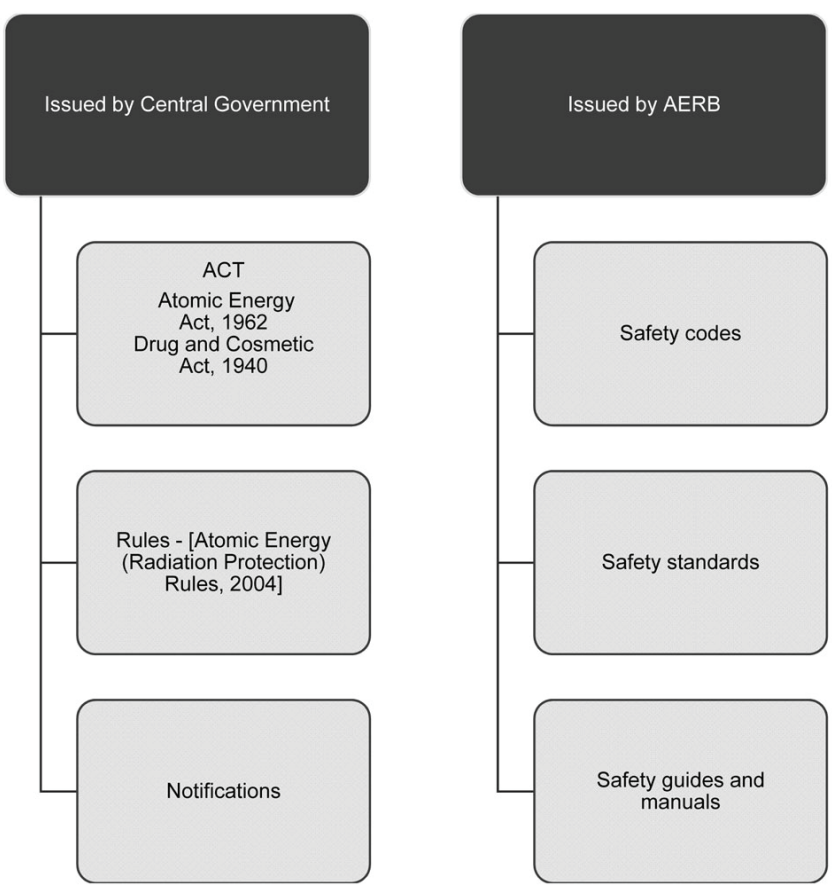

Figure 5. Regulatory set-up for radiopharmaceuticals in India.
Bhabha Atomic Research Center (BARC), Mumbai it carries out development, production and supply of radiopharmaceuticals to many nuclear medicine centres throughout the country. BARC supplies reactor-produced radioisotopes to BRIT, where they are processed leading to production of radiopharmaceuticals for their multifarious applications in healthcare and industry. These radiopharmaceuticals are produced by BRIT in strict compliance with regulations according to the Radiopharmaceutical Committee (RPC) guidelines. BRIT has six regional centers in different parts of the country providing a supportive role to its major units. BRITmanufactured radiopharmaceuticals are supplied according to a set dispatch schedules after RPC approval. Request for various products and services placed to BRIT is confirmed subject to prior approval/authorization of these interested laboratories/facilities by AERB. Any new order for product from BRIT is referred to AERB for obtaining prior authentication. BRIT is actively involved in the production and supply of a wide range of radiopharmaceuticals (Figure 6). These radiopharmaceuticals can be obtained from BRIT following successful completion and approval of A-1 form. However, cases exist where BRIT has not been able to meet the demands of most commonly used products like I-131 capsules, solution and injection. In such cases it has been conceived that direct import can be made for such compounds without any registration requirements ${ }^{41}$. Export of any BRIT product is subject to approval from DAE. BRIT has also been vested the responsibility of interaction with AERB regarding authorization and approval of transportation packages for disposal.

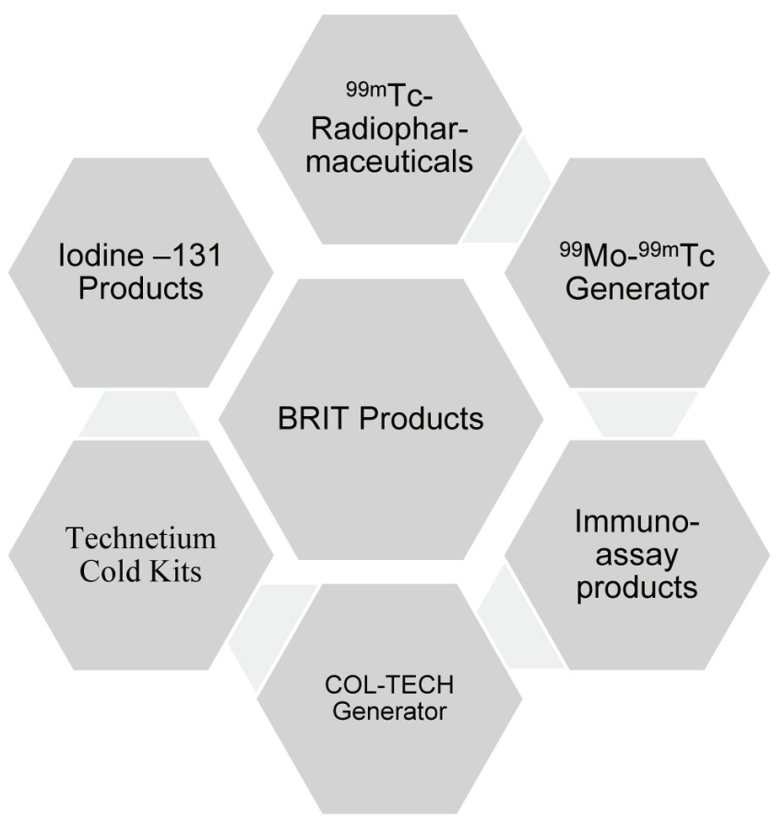

Figure 6. List of products supplied by the Board of Radiation and Isotopic Studies. 


\section{REVIEW ARTICLES}

Apart from radiopharmaceuticals, BRIT also supplies other products, including labelled compounds and nucleotides, gamma chambers, sealed radiation sources, blood irradiator and radiography exposure devices. BRIT has more than 200 products which are approved by RPC. However, it is imperative to note that BRIT approval of any product is limited to their sale product only. Many lacunae exist for such BRIT-approved products as quality control tests like sterility testing and LAL test are done according to 'suitable method' with regard to their protocols and do not bear reference to Indian Pharmacopoeia, which is critical keeping in view the quality concerns of such products. Moreover some radiopharmaceuticals can also be prepared 'onsite' in various hospitals and institutes for which there is no RPC approval and as such the matter pertaining to its quality remains contentious although they are produced in AERB licensed facility. Another cause of concern is the inconsistent and sometimes inordinate price tag for such locally produced products, indicating an indispensable need of the Drug Controller General of India (DCGI) to intervene in such matters, so that the benefits of technology are made available to all sections of society at an affordable cost.

The Drugs and Cosmetic Act 1940 and the associated rules govern the pharmaceutical industry in India ${ }^{42}$. The Act consists of chapters, rules and schedules and is amended at regular intervals to ensure greater safety, efficacy and drug quality. However, till date, radiopharmaceuticals enjoy immunity from the ambit of this Act, and as such any one can prepare and sell them. They are kept in Schedule K of Drug and Cosmetic Act and according to Rule 123 are exempted from the provisions of rules of its Chapter IV which concerns the manufacture, sale and distribution of drugs and cosmetics. They are not given the full status of a drug despite their diverse roles in biomedical research and healthcare. This is most probably done because the DCGI does not have any expertise in regulating radiopharmaceuticals, and the DAE units are the only ones manufacturing them. Therefore, the DAE had been mandated the task of regulating the radiopharmaceuticals they manufacture. Licensing by AERB includes strict compliance for preparation of pharmaceuticals and the use of radioactive materials. It is important for the user to be cognizant of the applicable requirements of the Drug and Cosmetic Act and any additional requirement of AERB and Indian Pharmacopoeia. AERB permission is required for the manufacture of radiopharmaceuticals, while their launch necessitates DCGI approval. Thus the present status concerning radiopharmaceuticals in India consists of various approvals and licensing according to AERB and the Drug Control Authority. Since, at present, radiopharmaceuticals are kept in Schedule $\mathrm{K}$ of Drug and Cosmetic Act, they enjoy immunity from many provisions and are not given full status of a drug. Therefore, in a move towards harmonization, it is imperative to remove radiopharmaceuticals from Schedule K of Chapter IV of Drug and Cosmetic Act so that they are given full status of drug for the purpose of implementing Indian Pharmacopoeia 2018, which consists of thirty five monographs of radiopharmaceuticals.

\section{Conclusion}

The increasing acceptance of disease-targeted treatment and rise in cancer patients coupled with high demand specifically from emerging countries like India, due to their noninvasive nature and the presence of potential radioisotopes in the pipeline have opened new frontiers for the ever-increasing radiopharmaceuticals market. However, to be used for human applications, it is imperative to have a seal of regulatory authority consent, which for radiopharmaceuticals is complex due to inadequate regulatory set-up, particularly in India. The national pharmacopoeia of many countries including the USP, European Pharmacopoeia, and Indian Pharmacopoeia have monographs of radiopharmaceuticals for establishing their quality. However, their use without regulatory approval can lead to enforcement action from national regulatory authority. Moreover, considering the high cost for various diagnostic and therapeutic uses of radiopharmaceuticals, it is imperative for a radiopharmaceutical to have an approved status to be qualified for possible reimbursement from third-party players. This has intensified the need for a quick and easy approval process to achieve sustainability in the commercial use of radiopharmaceuticals, as they can be unaffordable for patients particularly in developing nations like India. Therefore, it is imperative to examine the present regulatory landscape for radiopharmaceuticals approval, particularly in India. Efforts and legal framework ambient for entry of radiopharmaceuticals have become the utmost need of the hour, so that these drugs are delivered to mankind in the most cost-effective manner.

Conflict of interest: The authors declare that they have no conflict of interest.

1. Ramberg-Laskaris, K. L., Quality control in the radiopharmacy. J. Nucl. Med. Technol., 1984, 12, 33-36.

2. Saha, G. B., Quality control of radiopharmaceuticals. In Fundamentals of Nuclear Pharmacy, Springer, 1998, vol. 6, pp. 148172.

3. Volkert, W. A., Goeckeler, W. F., Ehrhardt, G. J. and Ketring, A. R., Therapeutic radionuclides: production and decay property considerations. J. Nucl. Med., 1991, 32, 174-185.

4. Kocher, D. C., Radioactive Decay Data Tables, Oak Ridge National Lab, USA, 1981.

5. Manuel Arruebo, M., Vilaboa, N., Sáez-Gutierrez, B., Lambea, J., Tres, A., Valladares, M. and González-Fernández, A., Assessment of the evolution of cancer treatment therapies. Cancers (Basel), 2011, 3, 3279-3280.

6. Richter, W. F., Starke, V. and Whitby, B., The distribution pattern of radioactivity across different tissues in quantitative whole-body 
autoradiography (QWBA) studies. Eur. J. Pharm. Sci., 2006, 28, $155-165$.

7. Wong, D. F., Potter, W. Z. and Brasic, J. R., Neuropsychopharmacology: The fifth generation of progress, Chapter 34. In Proof of Concept: Functional Models for Drug Development in Humans, Lippincott Williams and Wilkins, 2002, pp. 457-473.

8. Banerjee, S., Pillai, M. R. A. and Knapp, F. F., Lutetium-177 therapeutic radiopharmaceuticals: linking chemistry, radiochemistry, and practical applications. Chem. Rev., 2015, 115, 2934-2974.

9. Refining processes for the co-development of genome-based therapeutics and companion diagnostic tests: workshop summary. In Roundtable on Translating Genomic-Based Research for Health; Board on Health Sciences Policy, Institute of Medicine, The National Academies Press, Washington (DC), USA, 2014.

10. Nunn, A. D., The cost of developing imaging agents for routine clinical use. Invest. Radiol., 2006, 41, 206-212.

11. Hoffman, J. M., Gambhir, S. S. and Kelloff, G. J., Regulatory and reimbursement challenges for molecular imaging. Radiology, 2007, 245, 645-660.

12. Agdeppa, E. D. and Spilker, M. E., A review of imaging agent development. AAPS J., 2009, 11, 286-299.

13. Josephson, L. and Rudin, M., Barriers to clinical translation with diagnostic drugs. J. Nucl. Med., 2013, 54, 1-4.

14. Sharma, S., Baldi, A. and Sharma, R. K., Radiopharmaceuticals regulations on bioavailability and bioequivalence: present status and future requirements. Mod. Appl. Bioequiv. Bioavail., 2017, 1, 1-4.

15. Elsinga, P. et al., Guidance on current good radiopharmacy practice (cGRPP) for the small-scale preparation of radiopharmaceuticals. Eur. J. Nucl. Med. Mol. Imag., 2010, 37, 1049-1062.

16. Ziegler, S., Historical Role of the USP in Radiopharmaceuticals. In SNMMI Annual Meeting, Denver, Colorado, USA, 12 June 2017.

17. Food and Drug Administration Modernization Act (FDAMA), 1997; https://www.fda.gov/regulatoryinformation/lawsenforcedbyfda/ significantamendmentstothefdcact/fdama/default.htm (accessed on 1 July 2018).

18. Food and Drug Administration Amendments Act (FDAAA), 2007; https://www.fda.gov/RegulatoryInformation/LawsEnforcedbyFDA/ SignificantAmendmentstotheFDCAct/FoodandDrugAdministrationAmendmentsActof 2007/default.htm (accessed on 2 July 2018).

19. Notice of FDA exercise of enforcement discretion for PET drugs. June 2012; http://www.fda.gov/downloads/Drugs/Development ApprovalProcess/Manufacturing/UCM295267.pdf (accessed on 2 July 2018).

20. PET drugs - current good manufacturing practice (CGMP). US Department of Health and Human Services, Food and Drug Administration, Center for Drug Evaluation and Research (CDER), 2009.

21. PET drug applications - content and format for NDAs and ANDAs. US Department of Health and Human Services, Food and Drug Administration, CDER, USA, 2011.

22. Schwarz, S. W., Dick, D., VanBrocklin, H. F. and Hoffman, J. M., Regulatory requirements for PET drug production. J. Nucl. Med., 2014, 55, 1132-1137.

23. Hung, J. C., Bringing new PET drugs to clinical practice - a regulatory perspective. Theranostics, 2013, 3, 885-893.

24. Anjan, K. M., Sameeraja, N. H. and Murthy, P. N., Drug approval process - in United States of America, European Union and India: a review. Appl. Clini. Res. Clin. Trials Regul. Aff., 2014, 1, 13-22.

25. Raj, R. K., Pattanaik, P. and Roy, H., The dynamics of global Pharma regulatory affairs system. Indo. Am. J. Pharm. Sci., 2015, 1, 28-34.
26. Investigational new drug applications for positron emission tomography (PET) drugs. US Department of Health and Human Services, Food and Drug Administration, CDER, USA, 2012.

27. Lenaerts, K. and Desomer, M., Towards a hierarchy of legal acts in the European Union? Simplification of legal instruments and procedures. Euro Law J., 2005, 11, 744-765.

28. Scott, J. and Trubek, D. M., Mind the gap: law and new approaches to Governance in the European Union. Euro. Law J., 2002, 8, $1-18$.

29. Salvodri, P. A., Radiopharmaceuticals, drug development and pharmaceuticals regulation in Europe. Curr. Radiopharm., 2008, $1,7-11$.

30. Directive 65/65/EEC, 26 January 1965 , on the approximation of provisions laid down by law, regulation or administrative action relating to medicinal products. Official Journal of the European Communities; 369/65.

31. European Commission Directive 2001/83/EC of the European Parliament and of the Council of 6 November 2001 on the Community code relating to medicinal products for human. Offi. J. Eur. Union, 2001, 311, 67-128.

32. Hennings, G., Marketing authorizations of medicinal products in the European Union: past, present, and future. Ther. Innou. Regul. Sci., 2000, 34, 793-800.

33. Jürgen, F., Regulatory Europeanization, national autonomy and regulatory effectiveness: Marketing authorization for pharmaceuticals. MPIfG Discussion Paper, No. 02/6, 2002.

34. Kohler, M., Regulatory pathways in the European Union. $m A b s$, $2011,3,241-242$.

35. Schmidt, S. K., Mutual recognition as a new mode of governance. J. Eur. Public Policy, 2007, 14, 667-681.

36. Chavan, P. N., Vijayan, S., Joshi, M. M., Godse, N., Marialouis, J. and Kasibhatta, R., Marketing authorization procedures in Europe: a regulatory perspective. Int. J. Pharm. Pharm. Sci. Res, 2011, 1, 13-19.

37. Makvana, P. and Maheshwari, D., Regulatory requirements for marketing authorization of generic parenteral product in European countries by decentralized procedure. J. Pharm. Sci. Biosci. Res., $2014,4,145-149$.

38. EMA/821278/2015, Human Medicines Evaluation Division, European Medicines Agency pre-authorisation procedural advice for users of the centralised procedure, October 2018.

39. Guideline on Radiopharmaceuticals, Committee for Human Medicinal Products (CHMP); European Medicine Agency, November 2008.

40. Nuclear Medicine Facilities, CODE No. AERB/RF-MED/SC-2 (Rev. 2), Government of India, 2011.

41. Recommendations of the SEC (radio-diagnostic) made in its special meeting held on 14 July 2017 at Central Drugs Standard Control Organization Headquarters, New Delhi, 2017.

42. Ministry of Health and Family Welfare, The Drugs and Cosmetics Act, 1940, Government of India.

ACKNOWLEDGEMENT. We thank the I. K. Gujral Punjab Technical University, Jalandhar for support.

Received 7 August 2018; accepted 27 September 2018

doi: $10.18520 / \mathrm{cs} / \mathrm{v} 116 / \mathrm{i} 1 / 47-55$ 